\title{
RESISTANCE BY PLANT TISSUE HIGH IN SILICA TO INJURY BY CYANIDE AND MARINE BORERS
}

Because of comparatively ready availability-proximity to the ManatíCiales road-a large "jagüey" tree, Ficus laevigata L., heavily infested with "hormiguilla," the coffee shade-tree ant, Myrmelachista ramulorum Wheeler, was used for a number of years for conducting experiments in the control of this ant. Before Aldrin became commercially available, and indeed before its value in the control of hormiguilla had even been considered, the most promising method of killing these ants was to use bits of hamburg steak as an attractant, mixed with cyanide of potassium as a toxicant. Enormous numbers of ants were experimently killed using this combination of poison and bait, applied directly to the bark of the jagüey tree, without any indication of injury to the bark or any other part of the tree.

The tests were so successful indeed as to suggest continuation on a large scale in a commercial coffee grove on shade trees of Inga vera Willd. and Inga laurina (Sw.) Willd. A few weeks after application of the steak-cyanide

" "Insectae Portoricensis," a preliminary annotated check-list of the insects of Porto Rico, with descriptions of some new species, J. Dept. Agr. P. R., 7 (1) 5-313, 1923.

${ }^{8}$ Dispersion to the Tropics of the Spiraea aphid, Aphis spiraecola Patch, J. Agr. Univ. P. R., 39 (1) 32-40, fig. 1, ref. 14, 1955. 
mixture to the bark of these trees, considerable areas around the point of application were showing signs of injury as indicated by the boring exudations from the tunnels of shot-hole borer beetles, Xyleborus affinis Eichoff. If the steak-cyanide mixture was applied in a ring completely around the trunk of the tree, so that the ants could not avoid or by-pass it, the entire tree was killed. Clearly, some other arrangement had to be made if this poison bait were to be used on Inga trees, and the next development was to use flexible thin sheets of metal on which to place the bait, or containers of flexible metal. The fact that the bark of the jagüey tree had suffered no injury was completely ignored, and was hardly considered important, as it had no bearing on the hormiguilla control project. It is only now, in the light of quite different investigations by another worker, that it assumes significance.

The jagüey of Puerto Rico, Fiscus laevigata L., is an endemic tree, but of another species of fig, Ficus indica L., the marine biologist, C. H. Edmondson, reporting on "Resistance of Woods to Marine Borers in Hawaiian Waters", on page 43, writes: "Chemical analysis by Yard Testing Laboratory (U. S. Navy, Pearl Harbor, Oahu, T. H.): Wood contains less than 0.01 percent of silica, very light; alkaloids, none. Bark contains 2.30 percent silica; tannins, light; alkaloids, none."

He continues, that all of eight species of seasoned Ficus wood exposed six months in Honolulu harbor were

... badly damaged by teredos and usually lightly attacked by Limnoria. Greater resistance of green sections protected by bark was noted, especially of $F$. macrophylla, $F$. retusa, and $F$. rubiginosa. Seasoned bark of Ficus indica, $18 \mathrm{~mm}$. thick, used as test blocks was but lightly attacked by teredos during periods up to two years, with maximum penetration of $10 \mathrm{~mm}$., after which it showed evidence of failure. The resistance of this bark is probably due to its high silica content. Seasoned wood of this species, unprotected by bark, is riddled by teredos in five months.

Numerous investigators have stressed the importance of silica, and attributed the durability of particular woods under maritime conditions to the presence of considerable amounts of this substance in their tissues. D. R. Nanji, and W. S. Shaw, writing of "The Role of Silica in Plant Growth; its Assimilation and Physiological Relation to Phosphoric Acid" (Jour. Soc. Chemical Industry, Trans., 44 (1): 1-6, 1925), "conclude that about 90 percent of the total silica in plants is present as free silicic acid, probably in a colloidal state, whereas the other 10 percent is probably in combination with a polysaccharide constituent of the plant, in a form only to be extracted after treatment with acid. It is well known that silica may occur in the cells and fibers of plants in the form of granular inclusions which can be detected under proper technique.

George N. Wolcott

Department of Entomology

${ }^{1}$ Bishop, Bernice P., Museum Bulletin 217, pp. 91, fig. 27, ref. 38. 1955, Honolulu, T.H. 